\title{
The effect of motorcycle proportion on traffic flow parameters at multi-lane urban road
}

\author{
Titi Kurniati ${ }^{1, *}$, Rahmi Fajriati ${ }^{1}$ \\ ${ }^{1}$ Department of Civil Engineering, Universitas Andalas, Padang, Indonesia
}

\begin{abstract}
The phenomenon of traffic flows in almost all major cities of Indonesia is large dominance in the use of motorcycles. The change in the proportion of motorcycle users on the streets reaches more than $50 \%$. The author will discuss the effect of motorcycle volume proportion on traffic flow parameters such as speed and density. This research has been conducted at Ampang street with 4 lanes 2-way undivided type and Adinegoro street with 4 lanes 2-way divided type in Padang. By using Video Image Processor survey method, the data of traffic volume, and time travel of the vehicle for 12 hours were obtained. Further data is processed and the results are plotted into the graph by linear regression method. The results showed that the highest proportion of motorcycle volume of $75.9 \%$ occurred on Raya Ampang street and the lowest by 53.2\% occurred on Adinegoro street (to the North). The result of linear regression analysis where proportion of motorcycle volume ( $\mathrm{p})$ as variable $\mathrm{x}$ and space-meanspeed ( $\mathrm{S}$ ) as variable y is $\mathrm{S}=-0.687(\mathrm{p})+93.467, \mathrm{R}^{2}=0.8582$ at Ampang street, $\mathrm{S}=-1.3273(\mathrm{p})+143.75, \mathrm{R}^{2}=0.8153$ at Adinegoro street (to the south), and $\mathrm{y}=-1.3861(\mathrm{p})+131.94, \mathrm{R}^{2}=0.7882$ at Adinegoro street (to the north). Then the relationship between space-mean-speed, density, and traffic volume analyzed.
\end{abstract}

\section{Introduction}

In many ASEAN countries, motorcycles are a popular vehicle. The proportion of two-and three-wheeled vehicle of some ASIAN members was high as Vietnam (95\%), Indonesia (73\%), and Malaysia (49\%). The proportion of motorcycle on Malaysian roads varies from $35-75 \%$ depending on states [1]. Kusnandar's study on inter-city roads resulted in the proportion of motorcycle users on the streets reaches 60-70\% [2]. In West Sumatera Province, the motor vehicles development from 2012 to 2013 has increased in each mode of transportation with the average percentage of $5.81 \%$, where motorcycles were the mode with the most massive increase of $10.62 \%$ [3]. The result of research on urban roads on Bypass Padang road segments was the proportion of motorcycle volume ranging from $59.17-79.52 \%$ of traffic volume during peak hour [4].

\footnotetext{
*Corresponding author: titi@eng.unand.ac.id
} 
Motorcycles are considered capable of meeting the required transportation criteria. In addition to low prices so that anyone can afford it, this motor vehicle is fuel efficient, has the mobilization easier and faster. However, with the increasing proportion of motorcycles on the highway, it will undoubtedly affect the performance of the traffic flow such as speed and density. The model of the relationship between speed, density, and volume is used to determine how well a highway facility serves its users. In Indonesia to plan and evaluate traffic performance used by Indonesia's Highway Capacity Manual, MKJI 1997. When the preparation of MKJI was done, the condition of motorcycle proportion in the streets of urban areas in Indonesia is still around 30\%. [2] This can cause imprecision in road performance analysis. The purpose of this research is analyzing the effect of motor vehicle volume proportion with space-mean-speed and the relationship of volume and density to space-mean-speed on Ampang and Adinegoro street.

Space mean speed is expressed as the average speed of a vehicle in one part of the road at a certain time interval. To get the value of space mean speed has used Eq. 1 [5]:

$$
\mathrm{S}=\left(\left(\% \mathrm{MC} \times \mathrm{S}_{\mathrm{MC}}\right)+\left(\% \mathrm{LV} \times \mathrm{S}_{\mathrm{LV}}\right)+\left(\% \mathrm{HV} \times \mathrm{S}_{\mathrm{HV}}\right)\right) / 100
$$

where $\mathrm{S}=$ Space mean speed $(\mathrm{km} /$ hour$), \% \mathrm{MC}=$ proportion of motorcycle proportion $(\%)$, $\mathrm{S}_{\mathrm{MC}}=$ average speed of motorcycle $(\mathrm{km} / \mathrm{hour}), \% \mathrm{LV}=$ proportion of motorcycle proportion $(\%), \mathrm{S}_{\mathrm{LV}}=$ average speed of motorcycle $(\mathrm{km} /$ hour$), \% \mathrm{HV}=$ proportion of motorcycle proportion $(\%), \mathrm{S}_{\mathrm{HV}}=$ average speed of motorcycle $(\mathrm{km} / \mathrm{hour})$.

Traffic volume is the number of vehicles passing through a certain point during a certain time interval. The volume of traffic can be measured and expressed on an hourly basis [6].

Density is defined as the number of vehicles occupying a length of lane or road averaged over time. [6] Density is difficult to measure directly in the field but is calculated from the value of speed and volume as expressed in Eq. 2.

$$
D=\mathrm{V} / \mathrm{S}
$$

where $\mathrm{D}=$ Density (vehicle $/ \mathrm{km}), \mathrm{V}=$ Volume (vehicle $/ \mathrm{h}), \mathrm{S}=$ Space mean speed $(\mathrm{km} / \mathrm{h})$.

In MKJI 1997, the relationship between speed and traffic flow parameters on urban road single 2 lanes 2-way type as Fig.1 [6].

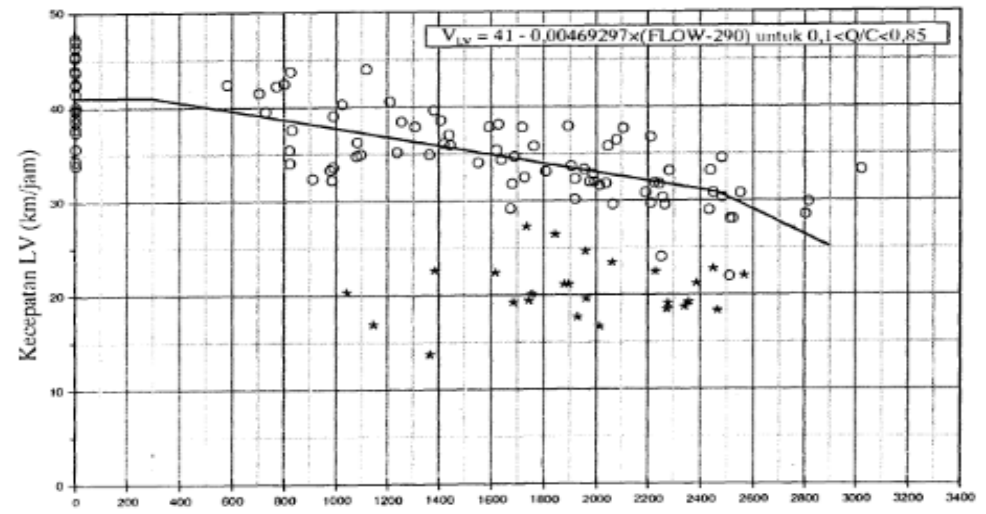

Fig. 1. The relationship between speed and traffic flow on undivided 2 lanes 2-way type.

The study of the influence of motorcycle proportions in traffic flow on a Bypass street in Padang which is an undivided 2 lanes 2-way type yields that the largest proportion of motorcycles that is $79.52 \%$ occurs at the morning peak hour (7.00-8.00 a.m.). The lowest occurs at 2.00-3.00 p.m. at 59.17\%. Linear regression analysis on space mean speed (Us) 
and proportion of motorcycle $(\mathrm{x})$ that is $\mathrm{Us}=77.61-0.35(\mathrm{x}), \mathrm{R}^{2}=0.583$. The relationship between Us and density $(\mathrm{K})$ ie Us $=63.92-0.187(\mathrm{~K}), \mathrm{R}^{2}=0.817$ [4].

\section{Methodology}

\subsection{Data collection}

The selection of survey sites by observing the speed of vehicles passing through the road segment is constant and unchanged unexpectedly. The criteria for obtaining the location are: 1) The selected road segment has no hassles due to vehicles that want to rotate, get into the wide lane, the presence of traffic lights and disturbance from pedestrians that can disrupt the smoothness of traffic; 2) Pavement condition and straight geometric design; 3) The survey was conducted in the middle of a road linking two intersections, either with traffic lights or not.[7] In this research, two survey locations with different types of roads were selected namely, Ampang street with 4 lanes 2-way single type, and Adinegoro street with 4 lanes 2-way divided type as shown in the Fig. 2.

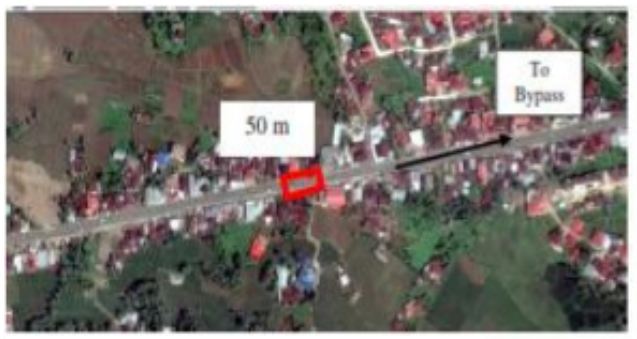

(a)

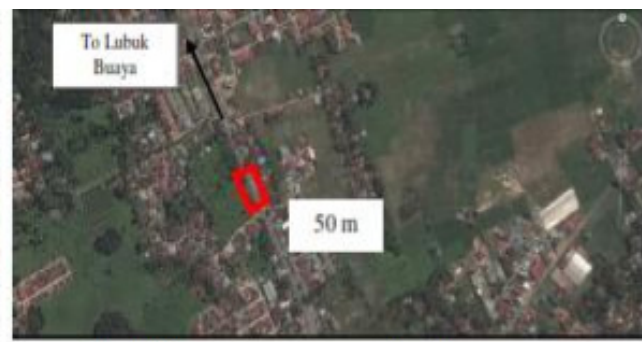

(b)

Fig. 2. Survey location map (a) Ampang street survey location map, (b) Adinegoro street survey location map.

The survey conducted for one working day from 6.00a.m to 6.00p.m for each road. On Ampang street held on Tuesday, April $25^{\text {th }} 2017$ and on Monday, May $8^{\text {th }} 2017$ on Adinegoro street. Implementation of the survey with the video image processing method that records the traffic volume and travel time of the vehicle along the 50-meter segment.

\subsection{Data processing}

Video recordings were observed with Avidemux media player. Every vehicle that passes through the designated road segment is calculated and classified into the type of vehicle. Vehicle classification is divided into three categories, namely, motorcycle (MC), light vehicle (LV), and heavy vehicle (HV). From the results of the recapitulation of traffic volume, the proportion of motorcycle volume is obtained. The speed of a vehicle is calculated based on the distance of the segment divided by the travel time. To achieve the average space velocity, the instantaneous speed classified is calculated by Eq. 1. Then linear regression is done to determine the relationship between speed and density.

\section{Result and discussion}

\subsection{Data description}

Fig. 3 and 4 shows the vehicle proportion data on Ampang street and Adinegoro street [8]. 


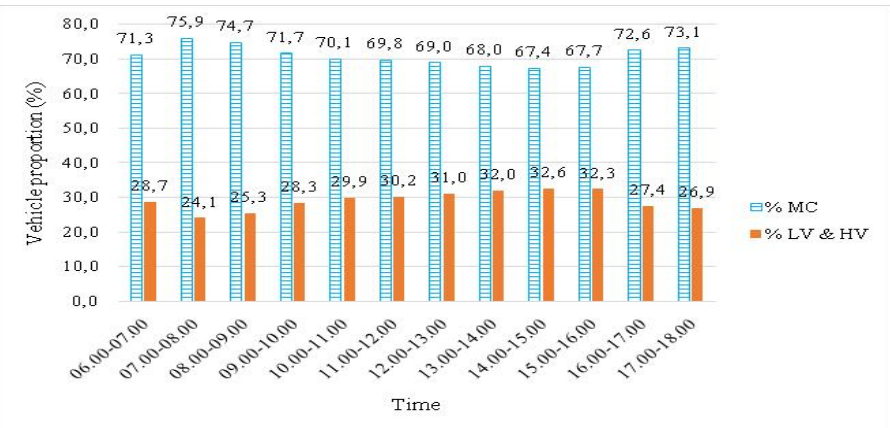

Fig. 3. The proportion of motorcycles against other vehicles on Ampang street.

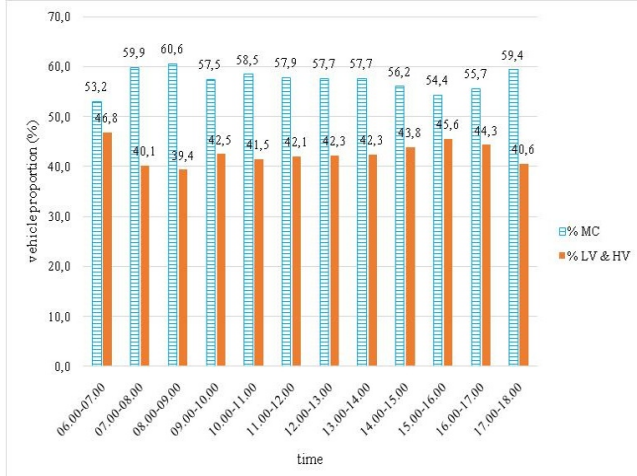

(a)

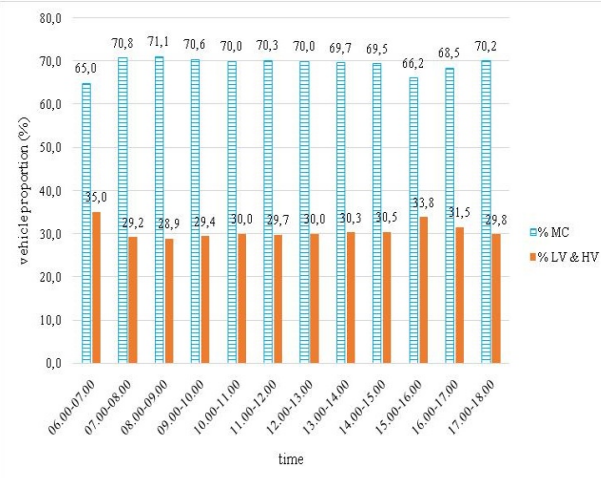

(b)

Fig. 4. The proportion of motorcycles against other vehicles on Adinegoro street, (a) volume proportion (\%) direction to North, (b) volume proportion (\%) direction to South.

In Ampang street, the highest volume proportion of motorcycles was $75.9 \%$, and the lowest was $67.4 \%$. In Adinegoro street direction to South the highest proportion of motorcycles was $71.1 \%$ and the lowest was $65.0 \%$, and the path to North the highest was $60.6 \%$ and the lowest was $53.2 \%$. The data of traffic volume and space-mean-speed is shown in Fig. 5 for the Ampang street and Fig. 6 for the Adinegoro street [8].

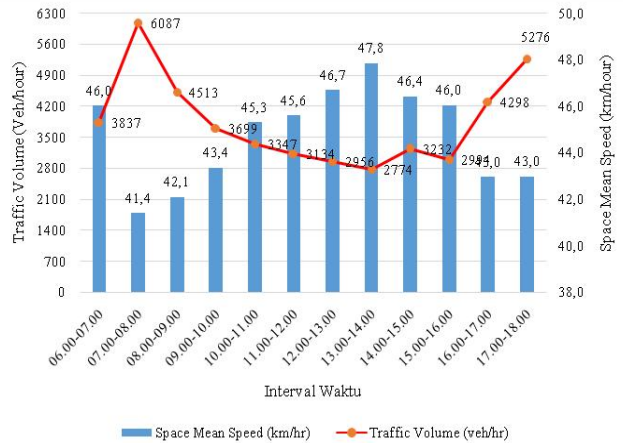

(a)

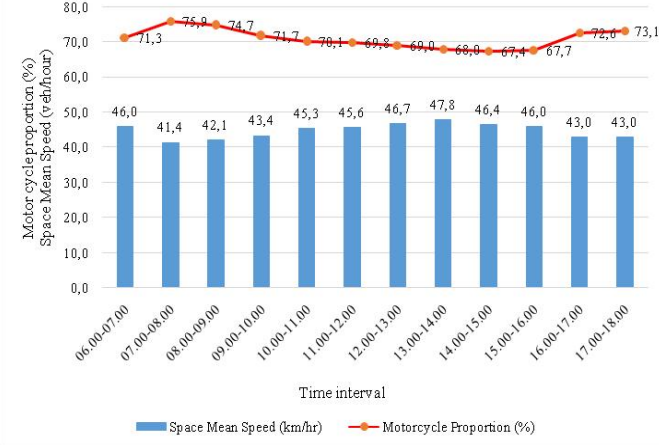

(b)

Fig. 5. Traffic volume and space-mean-speed on Ampang street, (a) direction to North, (b) direction to South. 


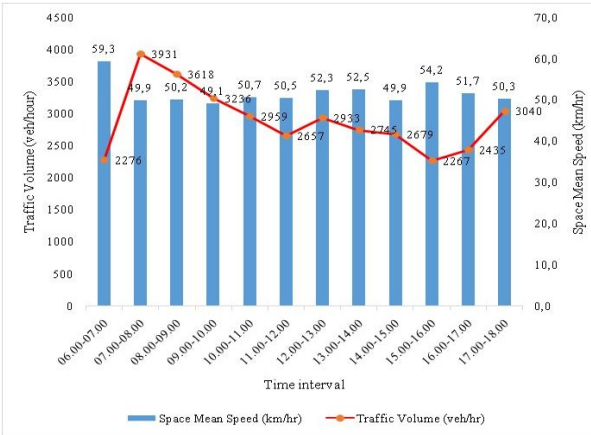

(a)

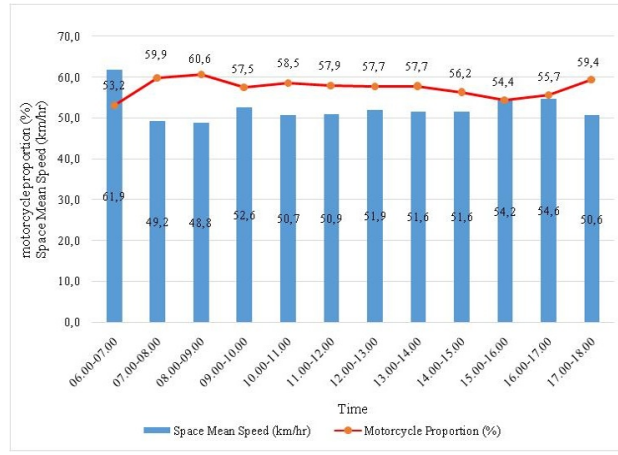

(b)

Fig. 6. Traffic volume and space-mean-speed on Adinegoro street, (a) direction to North, (b) direction to South.

From the figure obtained that the highest space-mean-speed on the Ampang street occurred at $1.00-2.00 \mathrm{p} . \mathrm{m}$. is $47.8 \mathrm{~km} /$ hour. At that time the lowest traffic volume of 2774 vehicle/hour (veh/hour). Conversely, the lowest speed occurred at 07.00-08.00a.m. of 41.4 $\mathrm{km} /$ hour, the highest traffic volume of $6087 \mathrm{veh} /$ hour. The same thing happens in Adinegoro street, just different peak time. (Fig. 6) [8].

\subsection{Analysis of the motorcycle proportion with traffic flow parameters relationship}

The result of linear regression of motorcycle volume proportion (p) to space mean speed (S) at Ampang street obtained the equation $\mathrm{S}=-0.687(\mathrm{p})+93.467$ with the coefficient of determination $\mathrm{R}^{2}=0.8582$. These results show that the volume proportion of motorcycles affecting the space mean speed as much as $85.82 \%$. This can be seen in Fig. 7. The same thing on Adinegoro street as shown in Fig. 8. Traffic flow to the North with the equation $\mathrm{S}$ $=-1.3861(p)+131.94, R^{2}=0.7882$ and to the South with equation $S=-1.3273(p)+143.75$, $\mathrm{R}^{2}=0.8153$.

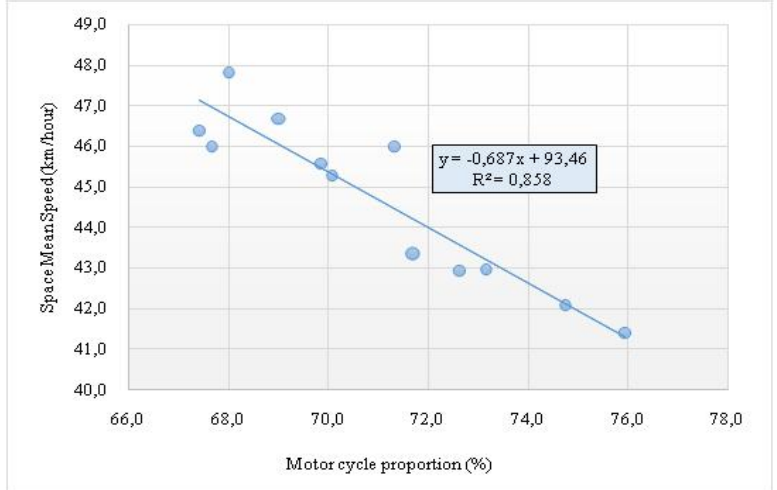

Fig. 7. Space-mean-speed vs motorcycle proportion on Ampang street.

Linear regression results of speed and density are shown graphically in Fig. 9 and Fig. 10 [8]. The graph above shows that the relationship between density (D) and space mean speed $(\mathrm{S})$ is negative linear. This means that the increase of density then space mean speed is getting smaller. Ampang street with motorcycle volume proportion of $67-76 \%$ got equation $S=-0.0684(D)+50.681$ with coefficient of determination value $R^{2}=0.8155$, 
meaning density happened at J1. Raya Ampang affects the space mean speed of $81.55 \%$ (Fig. 9). In Fig. 10, we get the equation $\mathrm{S}=-0.617(\mathrm{D})+73.45, \mathrm{R}^{2}=0.754$ direction to North and $\mathrm{S}=-0.173(\mathrm{D})+61.55, \mathrm{R}^{2}=0.538$ direction to South.

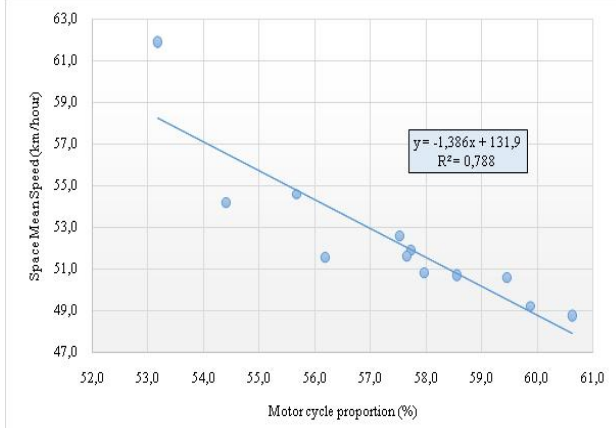

(a)

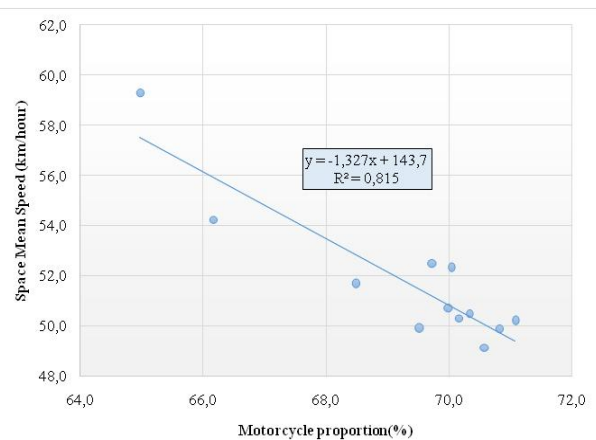

(b)

Fig. 8. Space-mean-speed vs motorcycle proportion on Adinegoro street, (a) direction to North, (b) direction to South.

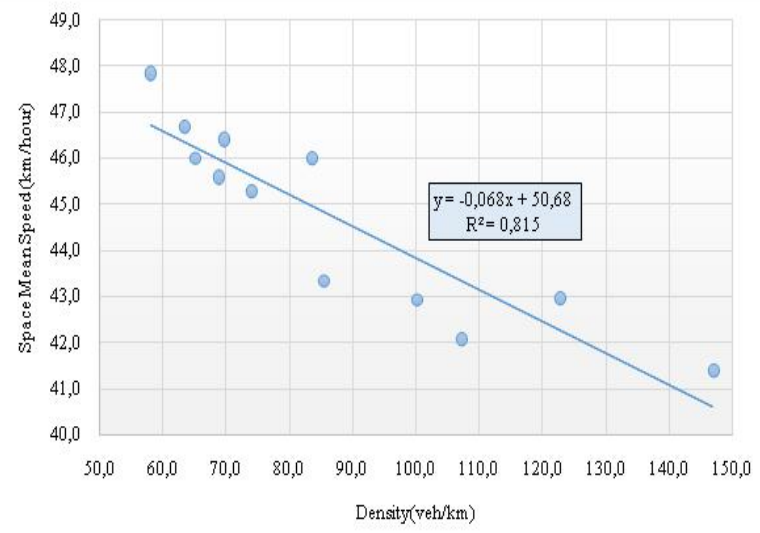

Fig. 9. Space mean speed vs density on Ampang street.

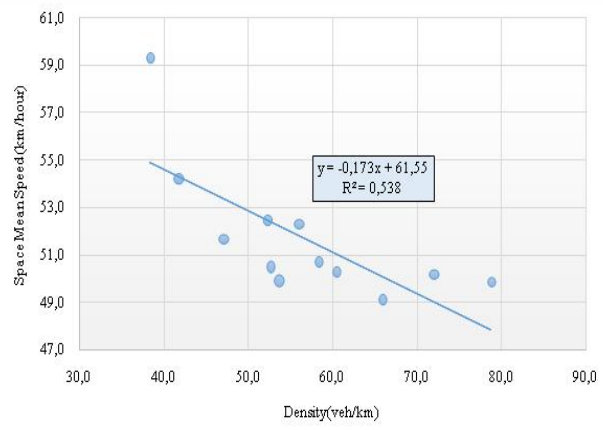

(a)

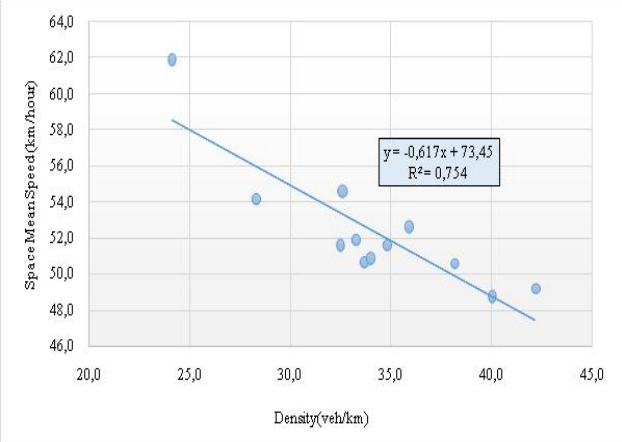

(b)

Fig. 10. Space mean speed vs density on Adinegoro street, (a) direction to South, (b) direction to North. 
The relationship of space mean speed and volume are also analyzed by linear regression. The result is $\mathrm{S}=-0.0018(\mathrm{D})+51.543$ with the coefficient of determination, $\mathrm{R}^{2}=$ 0.7732 which means the traffic volume affects the speed of $77.32 \%$ (Fig. 11). The resulting graph resembles with volume-speed relationship based on MKJI as shown in Fig. 1. The result of analysis on Adinegoro street is $\mathrm{S}=-0.0148(\mathrm{~V})+78.587, \mathrm{R}^{2}=0.5266$ direction to North and $\mathrm{S}=-0.0034(\mathrm{~V})+61.71, \mathrm{R}^{2}=0.397$ direction to North as shown in Fig. 12 [8].

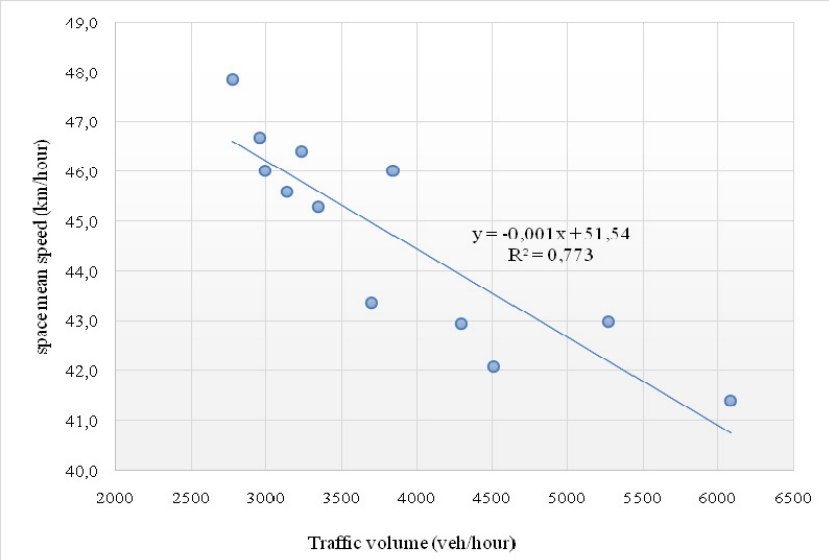

Fig. 11. Space mean speed vs density on Ampang street.

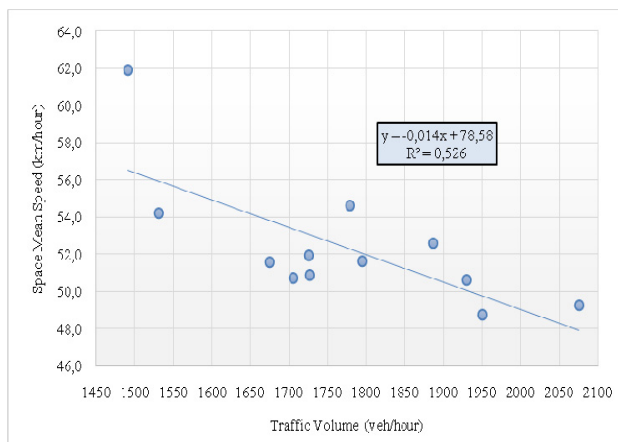

(a)

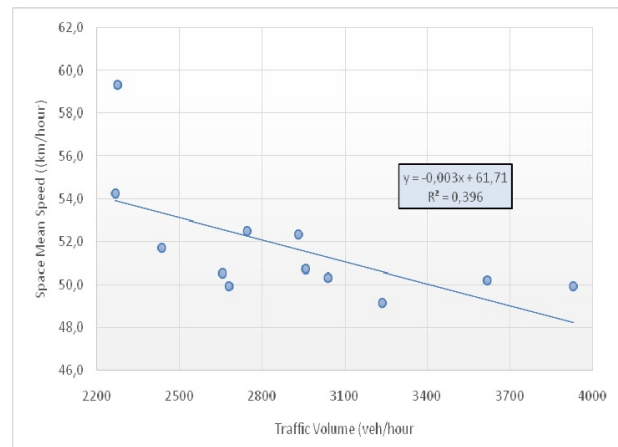

(b)

Fig. 12. Space mean speed vs volume on Adinegoro street, (a) direction to North, (b) direction to South.

Regression analysis results for the relationship between space-mean-speed-the proportion of motorcycles, density, and volume are given in Table 1. From Table 1 it can be concluded that the proportion of motorcycle volume on urban roads is more than $50 \%$. In this study ranges from $53-76 \%$. The increase is very significant $(77-137 \%)$ when compared to the proportion when MKJI 1997 was set at 30\%. The ratio of motorcycle volume influences space-mean-speed reductions $\left(\mathrm{R}^{2}>0.79\right)$. The percentage of motorcycle volume is proportional to the density and total volume of the vehicle. So that the density and volume have a significant effect on the space-mean-speed decrease. This will affect the design of urban road facilities. 
Table 3. Regression analysis result.

\begin{tabular}{|c|c|c|c|}
\hline $\begin{array}{c}\text { Relationship } \\
\text { between }\end{array}$ & Formulation & $\mathbf{R}^{2}$ & Information \\
\hline $\begin{array}{l}\text { p-S } \\
\text { S-D } \\
\text { S-V }\end{array}$ & $\begin{array}{l}S=-0.687(p)+93.46 \\
S=-0.068(D)+50.68 \\
S=-0.001(V)+51.54\end{array}$ & $\begin{array}{l}0.858 \\
0.815 \\
0.773\end{array}$ & $\begin{array}{c}4 \text { lane } 2 \text { way } \\
67-76 \% \text { motor cycle proportion }\end{array}$ \\
\hline $\begin{array}{l}\text { p-S } \\
\text { S-D } \\
\text { S-V }\end{array}$ & $\begin{array}{l}S=-1.386(p)+131.94 \\
S=-0.617(D)+73.45 \\
S=-0.014(V)+78.58\end{array}$ & $\begin{array}{l}0.788 \\
0.754 \\
0.526\end{array}$ & $\begin{array}{c}2 \text { lane } 1 \text { way } \\
53-61 \% \text { motor cycle proportion }\end{array}$ \\
\hline $\begin{array}{l}\text { p-S } \\
\text { S-D } \\
\text { S-V }\end{array}$ & $\begin{array}{l}S=-1.327(p)+143.75 \\
S=-0.173(D)+61.55 \\
S=-0.003(V)+61.71\end{array}$ & $\begin{array}{l}0.815 \\
0.538 \\
0.396\end{array}$ & $\begin{array}{c}2 \text { lane } 1 \text { way } \\
65-71 \% \text { motor cycle proportion }\end{array}$ \\
\hline
\end{tabular}

The authors would like to thank you for the financial support provided through Hibah Publikasi Fakultas Teknik Tahun Anggaran 2018 under contract no. 030/UN.16.09.D/PL/2018 from Engineering Faculty. We are grateful for Program Bantuan Seminar Internasional Dalam Negeri, Andalas University.

\section{References}

1. H. Hussain, M.S.A. Farhan, R.S.R. Umar, M.M. Dadang. IATSS Res. 29, 1 (2005)

2. E. Kusnandar, Jurnal Jalan dan Jembatan 27, 1 (2010)

3. BPS Padang, Padang dalam Angka 2014 (2015)

4. H. Helmar, Study of the effect of motorcycle proportion to speed on the urban road, (Undergraduate Thesis, Andalas University, 2014)

5. A. Syofyan, The effect of delman on traffic flow continuity on Gunung Batu street Bandung, (Undergraduate Thesis, Maranatha University, 2002)

6. C.J. Khisty, B.K. Lall. Transportation engineering: An introduction (Pearson, Boston, 2003)

7. Directorate General of Highways, Indonesia's Highway Capacity Manual, MKJI 1997, Jakarta (1997)

8. R. Fajriati, Study of the effect of motorcycle proportion on the traffic flow variables, (Undergraduate Thesis, Andalas University, 2017) 